\title{
E-Commerce: A Short History Follow-up on Possible Trends
}

\author{
Valdeci Ferreira dos Santos ${ }^{1}$, Leandro Ricardo Sabino ${ }^{2}$, Greiciele Macedo Morais ${ }^{3}$ \& Carlos Alberto Gonçalves ${ }^{4}$ \\ ${ }^{1}$ FUMEC University; Degree in Business Administration by PUC/MG; Graduate in Strategic Business Management \\ by FUMEC University; Worked as a Logistic Support Analyst at Companhia de Saneamento de Minas Gerais \\ (COPASA); Currently holds a Business Administrator position at Federal University of Ouro Preto; Ongoing \\ Master's in Business Administration by FUMEC University. \\ ${ }^{2}$ FUMEC University; Degree in Information Technology by the Centro Universitário Newton Paiva, Graduate in \\ Project Management by Fundação Getúlio Vargas, Currently holds the Coordination on Logistic Engineering at CMP \\ - Componentes e Módulos Plásticos; Ongoing Master's in Business Administration by FUMEC University \\ ${ }^{3}$ Federal University of Ouro Preto; Degree in Business Administration and Accounting by PUC/MG; Graduate in \\ Strategic Business Management by FUMEC University; Worked as Assistant Dean of Planning at Federal University \\ of Ouro Preto (UFOP); Currently holds a Business Administrator position at Federal University of Ouro Preto \\ (UFOP); Holds a Master's Degree in Business Administration by FUMEC University \\ ${ }^{4}$ FUMEC and UFMG; Professor at both FUMEC University and UFMG. Holds a PhD in Business Administration \\ by USP/SP and a Master's Degree in Computing by PUC/RJ. Currently teaches the subjects 'Strategy and Planning' \\ and 'Innovation and Entrepreneurship'. He runs a research project in Strategy and Marketology. Coordinator of the \\ Department of Research on Marketology and Strategy - NUME. \\ Correspondence: Greiciele Macedo Morais, Federal University of Ouro Preto, Brazil.
}

Received: November 2, 2017

Accepted: November 15, 2017

Online Published: November 20, 2017

doi:10.5430/ijba.v8n7p130

URL: https://doi.org/10.5430/ijba.v8n7p130

\begin{abstract}
The aim of this work is to think on the state-of-the-art of e-commerce and its trends for the future. E-commerce has been developing since the 1990's and its evolution is directly linked to the advancement of information technology. Early e-commerce began with the simple dissemination of goods and services by digital means, going from the issuance of orders, then the delivery of products to achieving interaction between traders and consumers via the Internet. Some e-commerce tools enable users to perform transactions even without leaving home - with transactions ranging from purchasing to paying bills. This can be done 24 hours a day, including weekends and holidays. The demand for convenience and, even, privacy are the main responsible reasons for the increased use of electronic commerce by consumers. Despite the advances of e-commerce in recent times it still requires larger investment, especially regarding safety, which is appointed as major deficiency in this trade modality, along with logistics. Investments will also be necessary to enable e-commerce to keep up with the current technological advances and future development prospects, such as the adoption of virtual intelligence, the expansion of globalization with language translators, adaptive interfaces that take into account the specific characteristics of user groups and the mobile commerce, and the experimentation in 3D model.This study aims to - by means of literature review - draw a brief history of the emergence and evolution of e-commerce, also highlighting the tools in use, the trends and challenges of this modern business model.
\end{abstract}

Keywords: e-commerce, internet, information technology, consumers

\section{Introduction}

Given the advances on the transmission, processing and storage technologies, presentation forms, ergonomics, information availability, speed and trustworthiness, more precisely with the development of the Internet, from 1990's, a large range of possibilities were noted - with a particular emphasis to communication. Some companies, having noticed the potential of that tool, stated using it to interact with their customers - at first, to divulgate information on their products, then to receive orders and, after that, to distribute products and services - up to arrival of the open arrival of e-commerce, which would cover even receipt and reverse logistics.

According to e-commerce in Brazil (EC) had its beginning approximately eight years ago, with a growing number of new companies to it, as well as a clientele which grows on a daily basis. Increased easiness to access the Internet was 
the driving force that pushed the increase in the number of new consumers to this new form of commerce. Authors say that trust in using the tools which enable electronic commerce usually comes after the experience of the first purchase.

According to (Tesche, 2013) some examples of products widely negotiated using electronic media, and purchased mainly by young people, are electronics, flight and show tickets, among other events. The same author highlights that the main attractive for consumers to use electronic media for shopping are access easiness and the fact that there is no presence of physical sellers, what makes consumers more comfortable while shopping.

Currently EC finds itself on a much consolidated phase, bearing in mind the steady development of IT, the easiness to access the Internet and the profile of this new consumer. Demands from that new consumer make companies develop themselves to keep competitive in the market where they operate. For that end they seek to keep up with market trends, the current one being the search for comfort by means of electronic commerce.

The present study aims at, by means of a theoretic review, outlining a short history of the beginning and evolution of electronic commerce, also highlighting the tools used and the trends and challenges of this modern model of commerce.

\section{Electronic Commerce}

In the next sections some aspects of EC are introduced. This explanation will enable the reader, giving more information on the emergence, evolution, concepts, tools, challenges and trends of this modality, as well as information on its relationship with the consumer.

\subsection{Emergence and Evolution of Electronic Commerce}

The evolution of EC has been studied and followed up by several researchers and stakeholders in the field. Given the advances on Information Technology, more precisely with the development of the Internet, from 1990's, a large range of possibilities were perceived, with a noted emphasis to communication.

Nevertheless, (Galinari et al., 2015) advocate that e-commerce has its first phase on the 1970's, when e-commerce was restricted to operations among large corporations which established among themselves private communication networks and, by means of electronic fund transfer systems, which electronically made financial transactions and document exchanges.

According to (Albertin, 2012) the evolution of EC can be divided in four phases. In Phase One, organizations used the functionalities of the Internet for processes of information divulgation regarding their product and services. That was the initial stimulus for EC development.

Still according to the author, the Phase Two was receiving orders and sending information and instructions on the utilization of their products and services. In this phase, logistics caused its first impact onto companies.

Phase Three of the evolution, according to (Albertin, 2012) was the distribution of products and services by using Information Technology (IT). In this phase, some products began to be commercialized digitally as, e.g., music and software.

For the last comes the phase which consolidates EC, with the interaction between seller and consumer, no more transmitting data or delivering products and services only. With the advance of IT and widespread use of the Internet, such interaction enabled the simple internet user to become a potential consumer, given the possibilities of EC. That tool allowed for a true revolution on how to commercialize products, services and information, bringing more comfort and large variety of offers and options for the consumer, but also for the seller who is inserted in that market practice.

For it is just normal that companies undergo transformations in their structure, and globalization contributed for that strong tendency. Increased competitiveness, the need of producing innovation and increasing consumer demands all items brought by globalization - have culminated with the emergence of more modern forms of company management.According to the authors, the advance in the access of broadband Internet in last years has become important for the development of EC. The appearance of a technology called 3G and 4G, from 2012 in Brazil, gave access to high speed Internet through mobile devices, such as smartphones and tablet PCs.

Such technology enables the consumer with more easiness to do price research for various locations. Some consumers use that resource even when inside physical stores, which they use to get in touch with the product, and there they choose the purchase channel of sales which better fits their shopping needs. 
The development of EC follows the stages of evolution of the digital environment - an evolution which must be understood and guaranteed through the aspects that must be taken into consideration when using the EC - aiming to assuring the use of its contributions. Thus, the development of information technology is impacted by the evolution on EC. Another dimension which completes the analysis on EC phases is its application in business processes (Albertin, 2000).

This way, electronic commerce became, much more than a trend, a reality. Modern companies seek to change their structure to comply with new consumers' demands, once the latter more and more value comfort. For such end, using new technologies is a very common strategy.

\subsection{Concepts and Types of Electronic Commerce}

Electronic commerce is the achievement/realization of the entire chain of value of the business processes by means of intense use of communication and information technologies, thus reaching the business's objectives (Albertin, 2000).

According to the author, the processes may be achieved, entirely or in part, in any of the transaction types set forth in Table 1, below. For him, such definition allows to understand that the achievement of that chain of values must include from distribution of information on products and services to the performance of transactions between the parties that compose the business environment.

According to the authors (Galinari et al., 2015) the Organization for Economic Cooperation and Development (OECD) defines, in 2011, the EC as purchasing and selling products or services managed through a digital environment and utilizing methods specifically idealized for the receipt or performance of commercial transactions. Still according to the authors, that such definition sets, as e-commerce, transactions whose orders are made using those methods, even when payments or deliveries are made without using the digital environment, restricted to operations performed using a computer network which provides a controlled external access.

The great advance of EC, as stated by (da Silveira Coelho et al., 2013), permits a large amount of transactions, which occur electronically, either between companies and consumers, between companies, between consumers and may also involve government organs. Table 1 below shows some information on the types of transactions possible by EC.

Table 1. Types of transactions possible in electronic commerce

\begin{tabular}{|c|c|c|}
\hline Acronym & Name & Description \\
\hline B2B & Business-to-business & Transactions between companies. \\
\hline $\mathrm{B} 2 \mathrm{C} / \mathrm{C} 2 \mathrm{~B}$ & Business-to-consumer/Consumer-to-business & $\begin{array}{l}\text { Companies making transactions between } \\
\text { companies and the end consumer. }\end{array}$ \\
\hline $\mathrm{C} 2 \mathrm{C}$ & Consumer-to-consumer & Transactions between end consumers. \\
\hline $\mathrm{G} 2 \mathrm{C} / \mathrm{C} 2 \mathrm{G}$ & $\begin{array}{l}\text { Government-to-consumer/ } \\
\text { consumer-to-government }\end{array}$ & $\begin{array}{l}\text { Transactions between government and end } \\
\text { consumers. }\end{array}$ \\
\hline B2G/G2B & $\begin{array}{l}\text { Business-to-government/ } \\
\text { government-to-business }\end{array}$ & 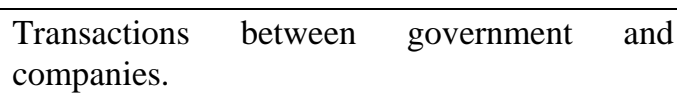 \\
\hline G2G & Government-to-government & $\begin{array}{l}\text { Transactions } \\
\text { departments. }\end{array}$ \\
\hline
\end{tabular}

Note. Source: Adapted from da Silveira Coelho et al.(2013).

Authors appoint that among the transactions mentioned in Table 1, the categories most done through electronic commerce are: $\mathrm{B} 2 \mathrm{~B}$ (Business-to-business), $\mathrm{B} 2 \mathrm{C}$ (Business-to-consumer) and $\mathrm{C} 2 \mathrm{C}$ (Consumer-to-consumer). For the major highlight goes for B2C, which has the larger number of transactions. Still according to the authors, in Brazil, the B2B commerce model is mostly comprised by commerce between industrial and commercial companies.

For the relevance of e-commerce expansion in current business scenarios is eminent, what requires the companies inserted in this model to operate differentiated and up-to-date strategies and approaches so they may reach their goals. 


\subsection{Main Tools in Electronic Commerce}

According to (Luciano, Testa, \& Freitas, 2003) the Internet is constantly improved, thus several applications often appear seeking to better utilization of the electronic commerce services.

E-procurement, according to (Luciano et al., 2003) is the automation of the purchase of products and services besides dynamism in purchasing, a considerable cost decrease can be noted, also a shorter decisory time can be reached.

Another important tool mentioned by (Luciano et al., 2003) is $\boldsymbol{e}$-learning, which is a tool that shortens distances between educators and students, providing them with conditions to access courses and training sessions wherever they are. Important examples may be mentioned, such as: language schools, virtual universities, etc.

An important and successful tool is e-banking, which, as mentioned by (Luciano et al., 2003), is good both for banking institutions and their clients. It enables clients to do, from home, what they would need to go to a bank branch to do, before. Besides bringing practicity to consumers, a considerable cost is reduced to banks.

$\boldsymbol{E}$-gambling is the tool for online casinos, with bets on money, which can be accessed by users located in any country, including those which do not allow traditional casinos, according to (Luciano et al., 2003).

E-auctioning are online auctions, which reduce costs with commuting and make traditional auctions more accessible and faster, as cited by (Luciano et al., 2003)

Many other tools were mentioned by (Luciano et al., 2003) as important ones for the development of electronic commerce, despite having a minor expression. For example: $\boldsymbol{e}$-trade, which is buying and selling stock shares online; $\boldsymbol{e}$-drugs, which are online drugstores, adding value to traditional drugstores, among others.

\subsection{Electronic Commerce Advantages}

According to (Lefebvre \& Lefebvre, 2002), electronic commerce has become an imperative environment for business. Opportunities it provides are so great there is no going back. As approached by the authors, electronic commerce provides competitive advantages, such as cost reduction, because it offers gains in precision and speed for the transactions on the Internet.

According to (Lefebvre \& Lefebvre, 2002) still another advantage of electronic commerce is giving visibility in the business world at low cost, making it possible to offer clients the opportunity of personalizing products and services.

Still according to authors, electronic commerce allows for marketing or micro marketing by means of data mining techniques, higher capacity of adapting to changes in the competitive conditions, and the capacity of optimizing supply chain in real time and of obtaining advantages through business partners' skills.

For (da Silveira Coelho et al., 2013) the industrial and commercial companies using B2B in Brazil are those which offer the clients the opportunity of product purchase and delivery at a location defined by the client.

According to (Kiang \& Chi, 2001), when it comes to B2B transactions, a great advantage electronic commerce provides is decreased processing time, which by consequence online companies get to keep lower levels of storage, thus reducing management cost and overhead maintenance. Another advantage mentioned by the authors is that the Internet provides fast adjustment to market conditions, which means it becomes possible to customize promotions and sales for individual clients.

According to (Kiang \& Chi, 2001), for products and services such as software, music, news, consultancy services, issuance of online tickets and reservations, banking services, among others, which use the Internet as a distribution channel, one can have not only delivery costs reduce but also immediate availability of products and services.

In Table 2 (Kiang \& Chi, 2001) propose a framework which puts together advantages electronic commerce provides, regarding marketing, within three groups: communication, transaction and distribution.

Table 2. Advantages of electronic commerce in marketing approach

\begin{tabular}{ll}
\hline Channel & Advantages \\
\hline Communication & Better information on products \\
& More information on Pricing \\
& Service availability, 24 hours, 7 days per week \\
& Lower communication costs \\
\hline
\end{tabular}




\begin{tabular}{ll}
\hline & Interactivity and trustworthiness for on-demand information \\
& Stock updates in real time \\
& Online technical support \\
& Fast response for clients' requests \\
& Customized orders \\
& After-sales service \\
& No personal contact \\
\hline Transaction & Virtual storefront viewable by all Internet users \\
& Lower transaction cost \\
& Allows micro transactions \\
& Human error reduction \\
& Purchase cycle time reduction \\
& Lower level of storage and other associated costs \\
& Possibility of customizing promos and sales for individual clients \\
& Price flexibility \\
& Relatively low initial investment and establishment cost \\
\hline Lower wait time for receiving digital products and services & Lower cost for delivery of digital products and services \\
& Allows clients to follow-up orders \\
& Reduces the number of representatives \\
\hline
\end{tabular}

Note: Source: Adapted from Kiang e Chi (2001).

\subsection{Challenges and Trends of Electronic Commerce}

To (Lefebvre \& Lefebvre, 2002), the electronic commerce causes a deep revolution in the way people do business; in such deep way an adaptation and learning period becomes necessary, both for companies and for consumers. There are obstacles to be overcome and a series of challenges for all involved stakeholders for e-commerce to be entirely developed.

According to the authors, forecasting how the new industries will develop is still a difficult task. Some newly-created segments are already changing, particularly Internet providers, where small ones are having more and more difficulty in competing with larger ones, which can offer their clients a wider range of services (modem or cable connection, ADSL [Asymmetric Digital Subscriber Line] technology, satellite links, etc.).

Regarding privacy, according to (Luciano et al., 2003), reconciling good service quality and privacy is still a challenge to be met for the Internet.

Still according to the authors, another challenge for commerce is delivery, because there is no trust on the EC customers' side on a perspective as to if products are to be delivered with the expected quality and, if that quality is not met, refunding will not be a hindrance.

According to (Diniz, 2008) the company-consumer relationship suggests availability of the technology related to access points and cost and usability, also related to user interface and communication, which are fundamental items for the evolution of the technology used in electronic commerce.

Another worrying factor according to (Diniz, 2008) is related to telecommunications where the Internet and its transactions have had a higher impact. According to the author, despite the increase in the revenue of telecom companies, bearing in mind their increased demand, their concern is that that demand is increasing at a faster pace than investments.

In the company-company relationship, electronic commerce needs to march forward having in mind there still is a trustworthiness gap as to safety systems, declares (Diniz, 2008).

According to (Cernev \& Leite, 2005), safety has been appointed by specialists as the greatest hindrance for the growth of electronic commerce in the world. And it has been responsible for billionary losses. That may be seen not only as a restriction, but also as an opportunity for growth. 
Authors appoint that those who are in charge of the development of electronic commerce should invest both on safety and on trustworthiness of their users. They are responsible for assuring that consumers, potential consumers and other users notice the existence and commitment to safety.

For (Diniz, 2008), with massive utilization of the Internet, another important factor which should be addressed is regulation, which according to the author must be more effective and explicit, to assure commercial transactions at a cost coherent with the traditional forms of commerce.

According to (da Silveira Coelho et al., 2013) the industrial and commercial companies in Brazil which use B2B are those which need investment the most for their conception, development and maintenance.

According to (Demo et al., 2014) there are relevant logistic challenges for the practice of electronic commerce with the growth of e-commerce in Brazil. According to the authors, logistics managers are being forced to implement diverse operational practices with the purpose of meeting the new form of consumer demand.

Authors also highlight that electronic commerce consumers tend to be more demanding than their traditional commerce counterparts. Those extra requirements and demands have required significant changes on online company operationalization dynamics, as well as bringing new solutions for client satisfaction.

For (Novak, Hoffmam and Yung, 2000) the characteristics of the online environment exert positive influences on the client's emotional and cognitive state during purchases. Corroboram (Ferreira et al., 2000) emphasizing that consumers are increasingly submerged and focused on their shopping experience when the virtual environment is more attractive.

To that end, they add (Trotti et al, 2017) that knowing the technology, functional logistics, providing a good relationship with the customer at all stages of the sales cycle in the virtual environment are crucial points for e-commerce and that need to be improved.

In addition to overcoming the challenges identified as providing greater security in purchases and payments, easy navigation layout with greater level of entertainment and interactivity, and other improvements that may impact on an improvement in the shopping experience, it is understood that a tendency for the continuous development and evolution of e-commerce runs through new technologies such as virtual 3D experimentation.

The experience of having access to all dimensions of the products in 3D model can be a source of benefits to the consumer in relation to the greater knowledge about the product, increase the possibility of finding a product or alternative more assertive, saving time, thus generating a greater pleasure and reliability in the online shopping process (Ferreira et al., 2015).

E-commerce is also about immersing itself in other technologies such as the adoption of virtual intelligence, the expansion of globalization with language translators, adaptive interfaces contemplating the characteristics of specific groups of users and mobile commerce as a way to improve the purchasing environment on-line and to improve the consumer shopping experience (Ferreira et al., 2015, Trotti et al., 2017, Nienow et al., 2017).

\subsection{Relationship with the Consumer}

According to (Kotler \& Keller, 2012), client-focused companies develop relationships, not only products or services. Still according to the authors, the success of organizations depends on the clients, from acquisition to maintenance to expansion. Clients are the only reason for developing products, installing factories, hiring employees, etc. With no clients, there is no business.

According to (Demo et al., 2014), it is necessary to highlight how the purchase experience takes place in the context of electronic commerce. According to (Kotler \& Keller, 2012), the latest forms of interactive marketing are the electronic channels. In this context there is a new form of client-company relationship, one in which the client starts and controls the process more and more. Clients are the ones who define what information they need, what offers they are interested on and which prices they are willing to pay, mainly considering how easy it is to compare prices on the Internet.

For (Demo et al., 2014), with the purpose of stimulating new visits to their virtual stores, companies must assess the context (layout) and content of their websites, given that, according to (Kotler \& Keller, 2012), visitors evaluate the performance of a virtual company basing on their website easiness to use and attractiveness.

According to (Anderson \& Srinivasan, 2003) facing the strong competition and growing expectation on the clients' side, electronic commerce companies are more and more interested in the identifying, understanding, taking care of and maintaining their profitable existing clients. 
Authors highlight that apparently many of their online clients compare the benefit package to be obtained to the costs to reaching the noted value. Clients, in the long run, also assess the cost of moving onto another competitor. This way, for a company to keep competitive it must continuously work on the noted value by the client and discourage his moving to any other competitor.

Still according to (Anderson \& Srinivasan, 2003), building trust relationships is a great challenge for companies, even coming to giving up part of their profits to differentiate themselves from their competitors. This way companies showing their clients that they are important and that the given companies want to help them, no matter what the short term profit consequences are, helps create or reinforce the type of trust which results in client loyalty.

For (Gefen, 2002), reaching client loyalty is an important objective for almost every profit-oriented business. As the author highlights, results of case studies show that reaching client loyalty depends on the capacity electronic commerce companies have to build and keep client trust by providing good quality service.

Good quality service of an electronic commerce company may be composed by three dimensions: Tangibility: a combination of response capacity, trustworthiness and safety and empathy. According to the author, the combination of responsiveness, trustworthiness and guarantee is the main dimension to increase client trust (Gefen, 2002).

According to (Kotler \& Keller, 2012), client satisfaction is the feeling of pleasure or disappointment on the performance of the value noted versus his expectation. If performance falls short of his expectation, the client will be dissatisfied; if performance meets the expectations, the client is satisfied. If performance is beyond the expectations, the client will be charmed.

Still according to the authors, a highly satisfied or charmed client stays loyal for the long run, and even more when the company comes to develop new products or services, besides speaking well of the company and spending less money on competitors, including being less sensitive to price changes.

\section{Final Provisions}

Electronic commerce history is connected to the evolution of information technology, but more specifically to the advances of the Internet. In this scenario, given the great advance of the Internet in recent years, any internet use becomes a potential consumer, and portable devices as mobile phones and tablet PCs began to more used for price researches and even for purchasing.

This new format of commerce has been successful due to the strong social demand for comfort. By its means it is possible doing transactions 24 hours a day, 365 day per year, across demographic frontiers, supported by the globalization phenomenon.

Despite the growing EC development, scholars state that for higher safety in this modality of commerce more investments become necessary to provide transactions with more safety and, in this scope, get closer to that of traditional commerce.

According to some authors, trust in this type of commerce emerges with the experience of the first purchase, and may be maintained, increased or reduced according to the meeting of expectations by suppliers.

E-commerce has become a reality and has been developing with information technology, so some of its limitations tend to be minimized, given the great technological advance in the present and great possibilities for development in the future, such as the adoption of virtual intelligence, expansion of globalization with language translators, adaptive interfaces contemplating the specific characteristics of groups of users and mobile commerce, and experimentation in 3D model.

This phenomenon is transforming the structures of organizations which are focused on becoming more competitive, because the business world currently demands from organizations a large capacity of adequating themselves to customers' needs. So, the utilization of information technology as a commerce tools becomes the source of a competitive differential, while opposition in maintaining an extremely conservative structure - resisting the implementation of IT tools - may be damaging to organizations' results.

This research demonstrates how e-commerce has developed in recent years, following developments in information technology and consumer needs. This rapid development generates an expectation that for the future e-commerce will be improved even more in a short time, by means of new technologies that stimulate the increase of the number of fans to this modality of commerce. For organizations, being aware of e-commerce trends for the next few years, can be a differential for their consolidation in the market. 
In this way the present work, by means of rhetorical review, seeks to contribute for the formation of potential consumers, those who may want to know and make e-commerce transactions, as well as to transmit this knowledge to traders on EC practices, its advantages, tools, challenges and trends. Nevertheless, this article presents as a limitation - its little depth on the theme - it suggests new works to come new researches to assess the impact of electronic commerce evolution onto organizations' routine and planning.

\section{References}

Albertin, A. L. (2000). O comércio eletrônico evolui e consolida-se no mercado brasileiro. Revista de Administração de Empresas, 40(4), 94-102.

Albertin, A. L. (2012). Comércio eletrônico: da evolução para as novas oportunidades. GVexecutivo, 11(2), 66-70.

Anderson, R. E., \& Srinivasan, S. S. (2003). E-satisfaction and e-loyalty: A contingency framework. Psychology \& Marketing, 20(2), 123-138.

Ban, C. A. B., Bauab, G. C., Lepiscopo, G. C. D., de Brito, J. A. N., Silva, L. L. G., \& de Moraes, C. A. (2016). E-COMMERCE E BENEFÍCIOS PROCURADOS: UM ESTUDO EXPLORATÓRIO. Jovens Pesquisadores-Mackenzie, 12(1). Retrieved from http://www.mackenzie.br/dhtm/seer/index.php/jovenspesquisadores/article/view/1307

Cernev, A. K., \& Leite, J. C. (2005). Segurança na Internet: a Percepção dos Usuários como Fator de Restrição ao comércio eletrônico no Brasil. ENCONTRO ANUAL DA ASSOCIAÇÃO NACIONAL DE PROGRAMAS DE PÓS-GRADUAÇÃO EM ADMINISTRAÇÃO, 29, 2005.

da Silveira Coelho, L., Oliveira, R. C., \& Alméri, T. M. (2013). O CRESCIMENTO DO E-COMMERCE E OS PROBLEMAS QUE O ACOMPANHAM: a identificação da oportunidade de melhoria em uma rede de comercio eletrônico na visão do cliente. Revista de Administração do UNISAL, 3(3). Retrieved from http://revista.unisal.br/sj/index.php/RevAdministracao/article/viewArticle/235

Demo, G., Alvarenga, B., \& Guarnieri, P. (2014). Validação de uma Escala de Avaliação do E-commerce (EAE): a Importância do Sistema Logístico e da Experiência de Compra. XVIII Encontro do ANPAD. Retrieved from https://www.google.com.br/search?q=Valida\%C3\%A7\%C3\%A3o+de+uma+Escala+de+Avalia\%C3\%A7\%C3 $\% \mathrm{~A} 3 \mathrm{o}+\mathrm{do}+\mathrm{E}-\mathrm{commerce}+(\mathrm{EAE}) \% 3 \mathrm{~A}+\mathrm{a}+\mathrm{Import} \% \mathrm{C} 3 \% \mathrm{~A} 2 \mathrm{ncia}+\mathrm{do}+$ Sistema+Log $\% \mathrm{C} 3 \% \mathrm{ADstico}+\mathrm{e}+\mathrm{da}+\mathrm{Experi}$ $\% \mathrm{C} 3 \%$ AAncia+de+Compra\&ie=utf-8\&oe=utf-8\&client=firefox-b\&gfe_rd=cr\&ei=bIw2V52_IuWp8weW37f4 AQ

Diniz, E. (2008). Comércio eletrônico: fazendo negócios através da Internet. em manutenção, 5(2), 56-61.

Ferreira, J. B., Freitas, A. S., Giovanni, C. J., Kurtz, R. K., Pina, F. (2015). Tecnologias Interactivas: efeitos no Varejo de Vestuário Online. Revista Eletrônica de Estratégia \& Negócios, Florianópolis, 8(2), 245-262.

Galinari, R., Cervieri Júnior, O., Júnior, T., Rodrigues, J., Rawet, E. L., \& others. (2015). Comércio eletrônico, tecnologias móveis e mídias sociais no Brasil. BNDES Setorial, Rio de Janeiro, (41). Retrieved from https://web.bndes.gov.br/bib/jspui/handle/1408/4285

Gefen, D. (2002). Customer loyalty in e-commerce. Journal of the Association for Information Systems, 3(1), 2.

Jacob, D. A., \& Silva, L. A. (2015). COMÉRCIO ELETRÔNICO: ATRAÇÃO E CONQUISTA DE E-CONSUMIDORES. INTERLINK, 2(2). $\quad$ Retrieved from http://187.45.244.77/ojs-2.4.6/index.php/InterLink/article/view/14

Kiang, M. Y., \& Chi, R. T. (2001). A Framework for Analyzing the Potential Benefits of Internet Marketing. J. Electron. Commerce Res., 2(4), 157-163.

Kotler, P., \& Keller, K. L. (2012). Administração de Marketing (14th ed.). São Paulo: Pearson Education do Brasil.

Lefebvre, L. A., \& Lefebvre, E. (2002). E-commerce and virtual enterprises: issues and challenges for transition economies. Technovation, 22(5), 313-323.

Lobosco, A., Alakija, A. F. da C., Zilber, S. N., \& Maccari, E. (2014). A INFLUÊNCIA DO COMÉRCIO ELETRÔNICO NAS PEQUENAS EMPRESAS DO SETOR DE MODA. Retrieved from https://repositorio.uninove.br/xmlui/handle/123456789/560

Luciano, E. M., Testa, M. G., \& Freitas, H. (2003). As tendencias em comercio eletrónico com base em recentes congressos. ASAMBLEA ANUAL DEL CONSEJO LATINOAMERICANO DE ESCUELAS DE ADMINISTRACIÓN-CLADEA, 38, 21-24. 
Nienow, A. L. (2017). INTERFACES ADAPTATIVAS NO COMÉRCIO ELETRÔNICO COMO FACILITADORAS DA INCLUSÃO DIGITAL DE IDOSOS. Tecnologia e Tendências, 9(2), 116-136

Novak, T.P., Hoffman, D.L., \& Yung, Y.-F (2000). Measuring customer experience in online environments: a structural modeling approach. Marketing Sciences, 19(1), 22-42.

Tesche, B. G. (2013). Estudo sobre as motivações na compra de produtos pelo comércio eletrônico. Retrieved from http://www.lume.ufrgs.br/handle/10183/132139

Trotti, F., Burgos, G., Júnior, G., Pavão, M. D. O. P. D., \& Pavão, O. (2017). Comércio eletrônico: como conquistar clientes e aumentar o faturamento em um ambiente virtual. Revista IT-Inovação \& Tecnologia, 1(1). 